\title{
History's Changing Climate: Climate Science, Genomics, and the Emerging Consilient Approach to Interdisciplinary History
}

\section{Citation}

McCormick, Michael. 2011. "History's Changing Climate: Climate Science, Genomics, and the Emerging Consilient Approach to Interdisciplinary History." Journal of Interdisciplinary History 42 (2) (September): 251-273. doi:10.1162/JINH_a_00214.

\section{Published Version}

doi:10.1162/JINH_a_00214

\section{Permanent link}

http://nrs.harvard.edu/urn-3:HUL.InstRepos:11595676

\section{Terms of Use}

This article was downloaded from Harvard University's DASH repository, and is made available under the terms and conditions applicable to Open Access Policy Articles, as set forth at http:// nrs.harvard.edu/urn-3:HUL.InstRepos:dash.current.terms-of-use\#OAP

\section{Share Your Story}

The Harvard community has made this article openly available.

Please share how this access benefits you. Submit a story.

\section{Accessibility}


Michael McCormick

History's Changing Climate: climate science, genomics, and the emerging consilient approach to interdisciplinary history.

A. Bruce Mainwaring, Robert Giegengack, and Claudio Vita-Finzi, eds., Climate crises in human history (Philadelphia: American Philosophical Society, 2010), p. 216.

Few would contest that the natural sciences are transforming the structures of knowledge. What are the implications for history? Abetted by the dizzying increase in computing power, the interpenetration of questions, data, and interpretations from the natural sciences and historical and archaeological investigations is accelerating. Today's historians scrutinize the interplay of environment and past societies, and climate scientists seek clues for the present in the past impact of climate change on civilizations.

Geneticists detect distant migration events in modern genomes and look to connect them to ancient population movements; to explain the material record of human experience, archaeologists rely routinely on high tech approaches ranging from ground-penetrating radar to the recovery of ancient DNA.

In 1979, this journal sponsored one of the earliest efforts to bring together scientists and historians to explore in interdisciplinary fashion "History and Climate." As it turned out, the issues, insights and questions vented there quickly outstripped the

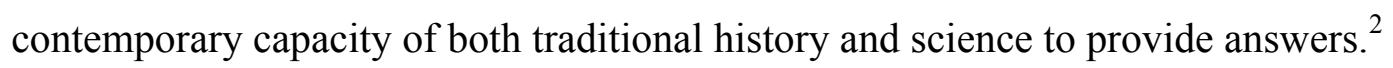

\footnotetext{
${ }^{1}$ Journal of Interdisciplinary History, 10 (1980), 581-858.

${ }^{2}$ Two scholars in particular deserve credit for pioneering efforts in climate history. H. H. Lamb, Climate, history and the modern world, 2nd ed. (London, 1995), originally published in 1982, synthesized climate scientist Lamb's investigations in this area and displayed an uncanny ability to make, from very sparse data, observations that still merit careful consideration today. The historian Le Roy Ladurie's probing investigation of European climate history began in 1959, long before the scientific breakthroughs of the last two decades when, for instance, the glaciochemical record leaves no doubt about the severity of the Little Ice Age: Emmanuel Le Roy Ladurie, "Histoire et climat," Annales: économies, sociétés, civilisations, 14 (1959), 3-34; and his synthesis, Histoire humaine et comparée du climat, 2 v. (Paris, 2004). For the glaciochemical evidence for the Little Ice Age, see, e.g. Sigfus J. Johnsen, Dorthe Dahl-Jensen, Niels
} 
Today, meetings and monographs return to these great questions, but they do so armed with rapidly multiplying new sets of scientific proxy data on past climates, with new science, and new questions. To track climate beyond the century or so covered by the recent instrumental record, scientists have invented ingenious "proxy" indicators for climate phenomena of all sorts, ranging from chemical analyses of ancient snowfalls preserved in glaciers to pollen trapped in finely laminated lake sediments or signals detected from tree rings. Sophisticated chemical analyses and modeling have shown that volcanic particles or oxygen isotopes in annual snow layers preserved in Greenland ice cores correspond to particular climate phenomena that may signal, for instance, rapid short-term climate change.

But the challenges of synthesizing the new data from science with the established traditions of human history and archaeology are not small. Compared to other recent collections, one new volume, Climate Crises in Human History is, both more multifarious, in time, space and the climate phenomena it investigates, and more uniform in attempting to privilege scientific data and its implications for historic and, mostly, prehistoric societies. ${ }^{3}$ This book is yet another sign of a broader historical turn toward

Gundestrup, Jørgen P. Steffensen, Henrik B. Clausen, Heinz Miller, Valerie Masson-Delmotte, Arny E. Sveinbjörnsdottir, and James White, "Oxygen isotope and palaeotemperature records from six Greenland ice-core stations: Camp Century, Dye-3, GRIP, GISP2, Renland and NorthGRIP," Journal of Quaternary Science, 16 (2001), 299-307.

${ }^{3}$ For example, in Ella Hermon, (ed.), Société et climats dans l'Empire romaine: pour une perspective historique et systémique de la gestion des ressources en eau dans l'Empire romain (Naples, 2009), the papers are as concerned with "social representations" as with society itself, in relation to environmental history and Roman hydrology, and emphasizes the Roman legal evidence concerning water resources. The scientific component comes principally from geomorphology, which is a useful but, by itself, very limited data set, and from Lamb's prescient but now dated work, based in large part on the written records of the time. Thus, for example, Hermon (12) evokes the possibility of a Roman warm period from the the fourth century B.C. to the fourth century A.D., with a "greenhouse effect" that operated from ca. 150 to 350 A.D., whereas recent and ongoing dendroecological work has been pointing for nearly a decade to much less stability in the western Roman Empire: see the early arguments of Burghart Schmidt, and Wolfgang Gruhle, "Niederschlagsschwankungen in Westeuropa während der letzten 8000 Jahre. Versuch einer Rekonstruktion mit Hilfe eines neuen dendrochronologischen Verfahrens," Archäologisches 
the natural sciences. As such it offers an apt occasion to sketch a development that will be heavy in consequences for the way we do interdisciplinary history, and to illustrate that interdisciplinary potential by examples ranging from the peopling of the Indian subcontinent to a pioneering homestead in nineteenth-century Illinois.

The strengths and weaknesses of the growing interaction of climate science, history and archaeology are clear in the eleven essays that address scattered but specific instances of climate variation and potential human responses from the Pleistocene to the Maya collapse in the ninth century A.D. Two scientists (R. Giegengack and C. VitaFinzi) outline in clear, critical and somewhat skeptical fashion what is known scientifically about climate change in the past and present. Starting from the reports of the Intergovernmental Panel on Climate Change, they usefully summarize some main scientific methods of palaeoclimate studies. Archaeologists explore the explanatory power of rather disparate data, ranging from fluctuations in solar radiation recorded in the context of radiocarbon dating (S. W. Manning) and their possible correlation with warming or cooling periods in western Eurasia since ca. 3000 B.C. (including the medieval warm period and the Little Ice Age), to animals in rock art as prehistoric climatic indicators (P. G. Bahn). The inevitable absence of ultra-precise chronologies at most archaeological sites underscores the difficulties of moving past chronological association to causality in gauging the "536 event," when an 18-month diminution of solar radiation provoked harvest failures across the late Roman empire of Justinian and

Korrespondenzblatt, 33 (2003), 281-300, and Burghart Schmidt, Wolfgang Gruhle, Andreas Zimmermann, and Thomas Fischer, "Mögliche Schwankungen von Getreideerträgen - Befunde zur Rheinischen Linienbandkeramik und Römischen Kaiserzeit," Archäologisches Korrespondenzblatt, 35 (2005), 301-316, and the 2011 study discussed below. In Wolfgang Behringer, Hartmut Lehmann, and Christian Pfister, (eds.), Kulturelle Konsequenzen der "Kleinen Eiszeit", Veröffentlichungen des Max-Planck-Instituts für Geschichte, 212 (Göttingen, 2005), the emphasis is explicitly on the written evidence for climate change, and the cultural consequences of the Little Ice Age, from witch hunts to increasing suicide rates. 
its neighbors (R. Hodges). Such difficulties are magnified in efforts to link the Younger Dryas cold period (ca. 12,900 cal. B.P.), extinction of the megafauna, and a deduced cosmic impact (S.J. Fiedel). A long-standing debate about Mediterranean erosion in late antiquity benefits from new radiocarbon datings and reflection on the possible impact of solar fluctuations on stream behavior and sediment transport over the last 10,000 years (C. Vita-Finzi). Not untypically, it appears that more data are needed rigorously to correlate hominin movements around North Africa with climate variability (J. R. Smith). A nuanced exploration of the very differing responses of Mesopotamian agrarian and pastoral economies around 3200 and 2200 B.C. offers a promising starting point for discussing the variegated and complex responses of early historical societies to climate change (M. D. Danti). By underscoring substantial variation that reflected both local differences and differing societies' varying economic strategies, such an approach is heartening, for it begins to move us beyond simplistic visions of climate-driven "collapse" and "growth." A comparative, anthropological approach (V. L. Scarborough and W. R. Burnside), seeks to clarify how Bali and Maya societies interacted with the specific challenges that arose from exploiting their tropical environments, while an archaeological perspective clarifies the potential and limits of the long-standing investigation of climate variability and the classic Maya collapse (N. Hammond). The final essay (M. Mormina and C. Higham) discusses how climate change and, in particular, sea levels, may have affected the peopling of southeast Asia as it is now emerging from archaeological and palaeogenetic investigation.

By emphasizing environmental phenomena that, by their nature, ignore national and cultural boundaries, these and similar studies drive home the urgency of the 
transnational, even global approach to history now gaining ground. One strength of the volume is the careful skepticism with which individual authors review particular case studies, a skepticism that arises in part from recognizing the difficulty of drawing firm causal connections between climate and societal response when chronological resolution falls short of the precision required by more traditional historical investigations. This is true for much of the climate data and all of the prehistoric archaeology that dominates the volume. That does not of course imply that interdisciplinary investigation of human responses to past climates is not worth pursuing. Rather, at this stage, it may be more productive to focus on times and places in which historical responses can be charted with greater chronological precision. That consideration is all the more compelling since the mechanisms and their effects argued by climate scientists on the basis of oceanic and atmospheric chemistry and mathematical modeling need corroboration over longer time scales than those afforded by the last hundred years or so of instrumental and historical records. Those records, after all, reflect the very unusual environmental conditions associated with the global Industrial Revolution. Scientists, it turns out, need historians and archaeologists as much as we need them. Only the deep written record of western Europe or China allows scientists and historians, working together, to verify that the postulated mechanisms did indeed produce the expected effects on human society before the Industrial Revolution, and to chart their severity and spatial scope over the kind of time scales that climate research necessitates.

An even more recent study uses established proxy mechanisms and the rings of 7,000 trees to reconstruct Central Europe's precipitation in April, May and June for every 
year between 250 B.C. and 2000 A.D. ${ }^{4}$ In this case, a historical approach tested the scientific results indicating years of extreme precipitation between 1000 and 1504 A.D., long before the Industrial Revolution began to affect global climate systems. For those centuries, 88 reports transmitted in 87 different contemporary chronicles and other historical records confirmed that the conditions deduced from the tree rings indeed occurred in the regions where the trees were growing for 30 of the 32 years of extreme precipitation that emerged from the dendrodata. Thus the medievalist's contribution in this case validated the scientists' results. The upshot is that historians of the last two and a half millennia can confidently turn to the new precipitation records for early summer rainfall in Central Europe, and begin to reflect on the implications for harvests and other precipitation-dependent phenomena of great historical import in any year of interest to them since 500 B.C.

Another approach has used spikes in sulfate deposits in the eighth- and ninthcentury snow still preserved as Greenland ice. They testify to very violent volcanic eruptions that have been shown to reduce the solar radiation reaching the earth, and occur ten times in ice layers dated between 750 and 950 A.D. According to widely accepted principles of climate forcing, much of that volcanic activity should have produced rapid and dramatic cooling periods. The historical records of Charlemagne's Europe and the contemporary Byzantine empire indicate that eight of the volcanic events documented and dated in the ice core analyzed by the Greenland Ice-Sheet Project 2 (GISP2) in fact correspond to extremely harsh winters recorded across multiple regions of western Eurasia. Although the volcanoes in question may well have been situated in distant Asia

\footnotetext{
${ }^{4}$ Ulf Büntgen, Willy Tegel, Kurt Nicolussi, Michael McCormick et al., "2500 Years of European climate variability and human susceptibility," Science, 331 (13 January 2011, 2011), 578-582.
} 
or America, the rapid climate changes they triggered did more than send icebergs floating down the Bosporus past Constantinople or allow carts to travel over a frozen Adriatic to the markets of Venice: they brought armies to a halt in France, and starved peasants and animals in Germany, Ireland and Byzantium. For the historian, the new scientific data unveil intelligible patterns of cause and effect in the hitherto unintelligible succession of devastating climate anomalies on a transcontinental scale. For the scientist, such a study demonstrates the human impact of a known climate mechanism. In some deep sense, Europe's deep historical record constitutes the ultimate in proxy records of climate change in the pre-instrumental era. ${ }^{5}$

Exciting though they are, palaeoclimate studies are only one small part of a broader confluence of scientific and historical investigation. That movement marks the beginning of something very new, a kind of archaeoscience of the human past, perhaps even a new kind of super-interdisciplinary history. This is not to say that science has made no contributions to historical understanding in preceding decades: no one involved in advanced archaeological investigations would maintain that, to cite only one obvious area beyond the pioneering efforts published in this journal. But what is happening now is quantitatively and qualitatively different. Scientists in areas as diverse as genetics, evolutionary biology, material and computer sciences ---just last January, Science published the birth certificate of a new kind of quantitative history from the 15 million books so far digitized in Google Books, dubbed "culturomics"-- are pushing relentlessly into areas that hitherto have been the exclusive province of the historian and

\footnotetext{
${ }^{5}$ As demonstrated recently by a collaboration of historians, an ice-core climatologist, and a biostatistician: Michael McCormick, Paul Edward Dutton, Paul A. Mayewski, and Nick Patterson, "Volcanoes and the climate forcing of Carolingian Europe, A.D. 750-950," Speculum, 82 (2007), 865-895, available online at http://www.medievalacademy.org/pdf/Volcanoes.pdf.
} 
archaeologist. ${ }^{6}$ What are the key features of the new historical turn of the sciences, and what do they mean for the practice of super-interdisciplinary history?

Consilience is surely one such feature. The nineteenth century originally fashioned this neologism (from the Latin words for "together" and "jumping, leaping") to designate the singularly robust epistemological status of inductions that proceeded from different classes of evidence. ${ }^{7}$ Today, consilience refers to the quality of investigations that draw conclusions from series of evidence that are epistemologically distinct. The term seems particularly apt for conclusions produced by natural scientific investigations on one hand, and by historical and archaeological studies on the other. Consilience points to areas of underlying unity of humanistic and scientific investigation, a unity arising from that of reality itself. When the results of such parallel but independent investigations converge, that is consilience, and that consilience makes our deductions much more robust. Like the rise of the new archaeoscience, consilience points toward a synthesis that can bridge the long-standing divide epitomized by C. P. Snow's "Two Cultures."

The new sciences of the human past expand the spectrum of historical evidence beyond even our wildest imaginings of just a few years ago. In practical terms, for the twenty-first century historian, consilience signals the contribution of the natural sciences to elucidating the human past, and the contribution of human history to clarifying and explaining the processes of nature itself. It is broad spectrum history in the truest sense. A

\footnotetext{
${ }^{6}$ Jean-Baptiste Michel, Yuan Kui Shen, Aviva P. Aiden, Adrian Veres et al., "Quantitative analysis of culture using millions of digitized books," Science, 331 (2011), 176-182.

7 "Consilience of inductions" is an expression invented by the nineteenth-century polymath William Whewell and reanimated in our time by the evolutionary biologist E. O. Wilson: William Whewell, The philosophy of the inductive sciences: founded upon their history (London, 1840), vol. 2, 230-231; cf., e.g., 270 and 446; Edward O. Wilson, Consilience: the unity of knowledge (New York, 1998), 8-14.

${ }^{8}$ C. P. Snow, Two cultures and the scientific revolution, The Rede lecture, 1959 (New York, 1959).
} 
few examples beyond climate history illustrate its potential, and articulate some of the main challenges that come with it, starting with human genetics.

The genomic revolution is about the evolution and transformations of the genetic code of life. Combined with advanced work in human palaeontology, the new sciences cast startling light on our original migration out of Africa and to subsequent events, such as the sexual interaction between Neanderthals and humans after Africa. ${ }^{9}$ The details emerging about the peopling of the planet are dissolving the barrier between "history" and "anthropology," and even raising questions of climate change, as one of the essays in Climate Crises suggests. They thereby restore to our perspective a far deeper and truer human past, the history of the few thousand generations, at least, which preceded the rise of literate societies in the Fertile Crescent and East Asia, as of the Americas. The boundary between "prehistory" and "history" vanishes as the exploration of the human past liberates itself from the ancient grasp of the salvation history of our ancestors and predecessors in the historian's craft. ${ }^{10}$

The "prehistorians" led the way in seizing and developing the powerful new tools emerging from the natural sciences. Their austere evidence comes overwhelmingly from the subtle traces of material remains that impose such innovative approaches. But over the last decade or so, many methods once confined to studies of Neolithic or Amerindian populations are increasingly trained on the civilizations whose study has until now relied largely on the written record. The new trend began in fields in which the written evidence is most uneven, and the demand for new data, strongest: the early medieval history of

\footnotetext{
${ }^{9}$ Richard E. Green, Johannes Krause, Adrian W. Briggs, Tomislav Maricic et al., "A draft sequence of the Neandertal genome," Science, 328 (2010), 710-722.

${ }^{10}$ See Daniel Lord Smail, "In the grip of sacred history," American Historical Review, 110 (2005), 1337-

1361, and, more broadly, Daniel Lord Smail, On deep history and the brain (Berkeley, 2008).
} 
Europe, Pre-Columbian civilizations documented mainly by the conquerors or the Maya inscriptions and codices, or sub-Saharan Africa before the European colonizers. Stable isotope studies, for instance, first targeted the transition from hunters to farmers by detecting the concomitant change in their diets. ${ }^{11}$ But the new trend is by no means limited to such fields.

Now stable isotopes illuminate, for instance, the unexpected implications of the rise of global trading networks in the daily lives of Renaissance Italians. Characteristic stable isotope ratios of the elements carbon and nitrogen situate an organism in the food chain. As one ascends a food chain or, more properly, trophic web, each organism keeps the isotopes of carbon and nitrogen found in its food and adds to them. This produces typical carbon and nitrogen isotopic ratios, that is, differences with respect to standard measures, determined by a mass spectrometer. Our bones and teeth preserve the enriched stable isotopic signature of the main food types we have eaten over several decades of life. Under medieval European circumstances, low carbon isotope ratios signify that a population ate mostly terrestrial plant food. Low nitrogen ratios indicate that they ate no marine food. A Harvard team compared the stable isotope ratios of two working class populations buried in two plague pits separated by almost a millennium. The first was buried in the time of pope Gregory the Great, around A.D. 600, at Castro dei Volsci, an early medieval rural community some twenty five kilometers from the sea and about eighty kilometers south of Rome. The second was inhumed in the 1470s in a cemetery on the site in Rome where the elegant Palazzo della Cancelleria was about to rise. The

\footnotetext{
${ }^{11}$ Margaret J. Schoeninger, Michael J. DeNiro, and Henrik Tauber, "Stable nitrogen isotope ratios of bone collagen reflect marine and terrestrial components of prehistoric human diet," Science, 220 (1983), 13811383; Stanley H. Ambrose, "Stable carbon and nitrogen isotope analysis of human and animal diet in Africa," Journal of Human Evolution, 15 (1986), 707-731.
} 
comparison of these two groups' stable isotopes uncovered an immense change in diet.

The early medieval rural population subsisted on an almost entirely plant-based diet, and

there was no sign of fish consumption. The population of Renaissance Rome, on the other

hand, displayed a surge in nitrogen isotope values, indicating a real jump in the

consumption of marine resources compared to similarly inland Mediterranean sites of

antiquity and the early Middle Ages. ${ }^{12}$ The evidence indicates so far that in the ancient

world, the working class people who got to eat fish in substantial quantities lived

practically on the seashore. Just a few kilometers inland from Ostia and the coast,

Roman marine consumption appears to drop off sharply. ${ }^{13}$ Because they were so

perishable and therefore expensive, only the rich could regularly eat fish away from the coast. $^{14}$

So scientific archaeology observes a dramatic shift in diet between two

populations living at a geologically insignificant distance in space, but 900 years apart.

To explain the change, we must return to the archives to discover a class of evidence that

is entirely independent of the Italian plague pits, yet converges perfectly with the

puzzling shift in stable isotope ratios. What had happened in the meantime was the growth of fish pickling, a method of preservation particularly suited to the herring's fatty

\footnotetext{
${ }^{12}$ Michal Salamon, Alfredo Coppa, Michael McCormick, Mauro Rubini, Rita Vargiu, and Noreen Tuross, "The consilience of historical and isotopic approaches in reconstructing the medieval Mediterranean diet," Journal of Archaeological Science, 35 (2008), 1667-1672.

${ }^{13}$ Tracy Prowse, Henry P. Schwarcz, Shelley Saunders, Roberto Macchiarelli, and Luca Bondioli, "Isotopic paleodiet studies of skeletons from the Imperial Roman-age cemetery of Isola Sacra, Rome, Italy," ibid., 31 (2004), 259-272.

${ }^{14}$ The evidence for an ancient fish preservation industry is growing; isotope results to date nevertheless indicate that it may have targeted a more well-to-do group of clients than the medieval and early modern trade in preserved fish. For recent archaeological investigations of the ancient preserved fish trade that may point to broader consumption than hitherto imagined see Wim Van Neer, and Anton Ervynck, "Remains of traded fish in archaeological sites: indicators of status, or bulk food?" in (eds.) S. Jones O'Day, W. Van Neer, et al., Behaviour behind bones: the zooarchaeology of ritual, religion, status and identity (2004), 203-214; on the archaeology of luxury foods, see Anton Ervynck, Wim Van Neer, Heide Hüster-Plogmann, and Jörg Schibler, "Beyond affluence: the zooarchaeology of luxury," World Archaeology, 34 (2003), 428441.
} 
flesh, and the spread of floating nets, which facilitated the capture of this abundant North Atlantic and Baltic fish. Europe's fishing industry, it now emerges, took off in the decades around $1000 .{ }^{15}$ Demand for the relatively cheap and long-lasting herring surged. The rising populations of Europe's emergent towns and bustling countryside were likely already outstripping the carrying capacity of the new-style agrarian organization which we now know was largely in place in the early Middle Ages, even as intensifying religious devotion translated into more widespread fasting that nevertheless allowed fish on Friday and other fast days. The Hanseatic League built a fortune on its barrels of pickled herring and, later, dried cod. ${ }^{16}$ But when did the Atlantic herring reach Mediterranean tables?

The question, as indeed that of fish in general seems not to have attracted much interest, for all the excellent studies of Mediterranean consumption of bread, meat, oil and wine in the last decades. ${ }^{17}$ The high cost of overland transport suggests that the bulk import of pickled herring had to await direct sea links between northern Europe and the Mediterranean, which the Genoese and then the Venetians only opened in the decades

\footnotetext{
${ }^{15}$ On the biology and medieval archaeology of the herring, see, e.g., D. Heinrich, "Hering," Reallexikon der Germanischen Altertumskunde 14 (Berlin, 1999), 416-419; on floating nets, e.g., Wim Van Neer, and Anton Ervynck, "The zooarchaeological reconstruction of the development of the exploitation of the sea: a status quaestionis for Flanders," in (eds.) M. Pieters, F. Verhaeghe, et al., Fishery, trade and piracy. Fishermen and fishermen's settlements in and around the North Sea area in the Middle Ages and later, Archeologie in Vlaanderen. Monografie, 6 (Brussels, 2006), 95-103, here 98. For the new evidence for the rise of the fishing industry around 1000: James H. Barrett, Alison M. Locker, and Callum M. Roberts, “'Dark Age Economics' revisited: the English fish bone evidence AD 600-1600," Antiquity, 78 (2004), 618636.

${ }^{16}$ For the early medieval agrarian revolution, see Joachim Henning, "Revolution or relapse? Technology, agriculture and early medieval archaeology in Germanic Central Europe," in (eds.) G. Ausenda, P. Delogu, et al., The Langobards before the Frankish conquest: an ethnographic perspective (Woodbridge, 2009), 149-173; for the Hansa's herring, Carsten Jahnke, Das Silber des Meeres: Fang und Vertrieb von Ostseehering zwischen Norwegen und Italien (12.-16. Jahrhundert), Quellen und Darstellungen zur hansischen Geschichte, n. F., 49 (Cologne, 2000).

${ }^{17}$ See for instance the bibliography of Brigitte Marin, and Catherine Virlouvet, (eds.), Nourrir les cités de Méditerranée: antiquité, temps modernes (Paris, 2003), 839-866.
} 
around $1300 .{ }^{18}$ In 1319 the canonization proceedings of Thomas Aquinas $(\dagger 1274)$

confirm this. On his deathbed south of Rome, that very big man with a very big appetite hankered for fresh herring. Of course they were completely unknown in Italy --"they are found across the Alps in England and France"-- and it took a miracle to produce a barrel for him. Skeptical, the ecclesiastical investigators asked the Italian eyewitness how he could tell they were herring: clearly the investigators assumed that in any form, this fish was unfamiliar in Italy. The witness' response bears out that herring were still not common fare in 1319: he only recognized the fish because he had once seen pickled herring at the papal court. Moreover another Dominican who was present had seen and eaten fresh herring in northern Europe and confirmed his impression. ${ }^{19}$

Around 1340, Pegolotti's famous handbook for merchants mentions pickled herring, but this could reflect the trader's own experience at Antwerp. ${ }^{20}$ Only in 1384 do we find the first mention of bulk herring shipments to Italy. The merchant Francesco Datini's fabulous business archive records a Genoese ship that loaded more than 640,000 herring in England. From Genoa they were shipped to Pisa and points south, and this likely would have included Rome. ${ }^{21}$ According to Datini's records, the big shift came in the 1390s, when the volume of fish cargoes loaded at Bruges and in English ports for Italy surged for good, and Datini appointed special representatives in London and Bruges

\footnotetext{
${ }^{18}$ Some pickled herring were in fact carried across the Alps as $15^{\text {th }}$ - and $16^{\text {th }}$-century toll tariffs prove, but, given the transport costs, this could be only a luxury trade: Jahnke, Das Silber des Meeres, 259.

${ }_{19}$ Processus canonizationis a. 1319 (BHL 8150), c. 50, ed. M. H. Laurent, Fontes vitae S. Thomae Aquinatis (Saint-Maximin, 1932), 267-407, here 332-334; cf. c. 9, p. 279. The quote is from the response of Thomas' companion to the dying saint's question about finding some herring to eat.

${ }^{20}$ Francesco Balducci Pegolotti, La pratica della mercatura, ed. Allan Evans (Cambridge, MA, 1936), 253, 380; cf. the glossary, 411 and 413 s.vv. "aleccis" and "aringhe insalate."

${ }^{21}$ Giampero Nigro, "Mangiare di grasso, mangiar di magro: il consumo di carni e pesci tra Medioevo ed Età moderna," in (ed.) S. Cavaciocchi, Alimentazione e nutrizione secc. XIII-XVIII (Florence, 1997), 113143 , at 120 .
} 
to oversee herring shipments. ${ }^{22}$ The late medieval Italian trade in pickled herring even

played a role in the Sephardic family history of a distinguished American economic

historian, according to a remarkable and hitherto unrecorded oral tradition. ${ }^{23}$ The

consilience of the isotopic profiles of the bones of Renaissance Romans with the archives

of a Tuscan businessman increases our confidence that the historical pattern detected here

is robust. The laboratory data puts fish in the stomachs of specific fifteenth-century

Romans, adding new detail and nuance even to the rich archival record of Renaissance

Italy.

Charlemagne's volcanoes and Renaissance herring are but two examples of the many new and independent lines of consilient investigation and evidence that are now emerging to clarify different historical problems. The tools of modern scientific archaeology illuminate the historical questions of the Jamestown colony or Champlain's 1605 winter ordeal in Maine. ${ }^{24}$ Biomineralogists' brilliant quantitative insights have

\footnotetext{
${ }^{22}$ Ibid. 121, and the summaries of herring cargoes from the Datini archives, 133-136, from 1384 to 1410 .

${ }^{23}$ A discussion of my research with my friend and colleague Henry Rosovsky prompted him to share a story which, in light of the above, appears both to offer a startling historical confirmation of the import of that trade and to testify to an oral tradition which looks to have lasted 500 years in the Italo-Sephardic family of Robert S. Lopez (1910-1986), Sterling Professor of Medieval History at Yale. As Rosovskly remembers this story, when the Jews of Spain were faced with forced conversion, presumably at the time of the Expulsion in 1492, Lopez's ancestors decided that the eldest son would keep the ancestral religion; they sent him to Italy to start life anew as a merchant with one sole asset, a barrel of pickled herring. When he arrived in Genoa, he opened the barrel to sell the herring, and discovered that his family had concealed gold in its bottom. Rosovky's brother Alexander Rosovsky (later Ross) worked with Lopez at CBS in New York during World War II, and heard the story from Lopez at that time.

${ }^{24}$ For example, archaeology, chemical analysis and archival materials illuminate the copper supply and working at Jamestown: Carter C. Hudgins, "Articles of exchange or ingredients of New World metallurgy? An examination of the industrial origins and metallurgical functions of scrap copper at early Jamestown (c. 1607-17)," Early American Studies: An Interdisciplinary Journal, 3 (2005), 32-64; bioarchaeology has much to tell about the fate of Champlain's crew in Maine in the winter of 1605: Thomas A. Crist, Marcella H. Sorg, Robert Larocque, and Molly H. Crist, "Champlain's cemetery: skeletal analysis of the first Acadians, Saint Croix Island International Historical Site, Calais, Maine," Unpublished report prepared for the United States National Parks Service, Acadia National Park, Bar Harbor, Maine (2005), knowledge of which I owe to the collegial friendship of Dr. Steven Pendery of the U.S. Parks Service.
} 
recovered the functional structure of vanished Masai compounds in western Africa. ${ }^{25}$

Today the tooth mutilation advertised as distinguishing features of runaway slaves in $18^{\text {th }}$-century wanted posters enables archaeologists to distinguish between American- and African-born slaves based on the filed teeth of their skeletal remains. Scientists confirm that deduction by analyzing the lesser lead content or the stable isotope profiles of their bones that reflects a childhood far from the lead pollution of the colonial Americas. ${ }^{26}$ Tomorrow, combining these approaches with genomic evidence will reveal where in Africa the captives were born, and expand the testimony of the slavers' logs and account books which care only where they were bought. ${ }^{27}$ And it is to genomics that we owe certain knowledge of Thomas Jefferson's sexual union with his young slave Sally Hemings, a fact whose reverberations in the minds of professional and general public alike are far from stilled. ${ }^{28}$ Such stunning new evidence about important historical

\footnotetext{
${ }^{25}$ Ruth Shahack-Gross, Fiona Marshall, Kathleen Ryan, and Steve Weiner, "Reconstruction of spatial organization in abandoned Maasai settlements: implications for site structure in the Pastoral Neolithic of East Africa," Journal of Archaeological Science, 31 (2004), 1395-1411.

${ }^{26}$ Jerome S. Handler, "Determining African birth from skeletal remains: a note on tooth mutilation," Historical Archaeology, 28 (1994), 113-119; cf. the convergence of strontium isotopes and tooth filing in the individuals from the Spanish $16^{\text {th }}$ - and $17^{\text {th }}$-century coastal cemetery: T. Douglas Price, Vera Tiesler, and James H. Burton, "Early African diaspora in colonial Campeche, Mexico: strontium isotopic evidence," American Journal of Physical Anthropology, 130 (2006), 485-490.

${ }^{27}$ Hannes Schroeder, "Isotopes, population genetics, and the transatlantic slave trade: reconciling individual and population-based approaches," paper given at the $3{ }^{\text {rd }}$ International Symposium of Biomolecular Archaeology, York [U.K.], 14-16 September, 2008; abstract at https://sites.google.com/a/palaeo.eu/isba3/Home/abstracts/populations/isotopes-population-genetics-andthe-transatlantic-slave-trade-reconciling-individual-and-population-based-approaches.

${ }^{28}$ For the genomic research see Eugene A. Foster, M. A. Jobling, P. G. Taylor, P. Donnelly, P. de Knijff, Rene Mieremet, T. Zerjal, and C. Tyler-Smith, "Jefferson fathered slave's last child," Nature, 396 (1998), 27-28, and Eric S. Lander, and Joseph J. Ellis, "Founding father," Nature, 396 (1998), 13-14; cf. Eliot Marshall, "Which Jefferson was the father?" Science, 283 (1999), 153-155, and the historians' reaction: Jan Lewis, Joseph J. Ellis, Lucia Stanton, Peter S. Onuf, Annette Gordon-Reed, Andrew Burstein, and Fraser D. Neiman, "Forum: Thomas Jefferson and Sally Hemings Redux," The William and Mary Quarterly, 57 (2000), 121-210. The genomic deduction seems reinforced by more recent research into the rareness of Jefferson's haplotype: Turi E. King, Georgina R. Bowden, Patricia L. Balaresque, Susan M. Adams, Morag E. Shanks, and Mark A. Jobling, "Thomas Jefferson's Y chromosome belongs to a rare European lineage," American Journal of Physical Anthropology, 132 (2007), 584-589.
} 
questions suggests that soon knowledge of the past may no longer be "primarily present to us in textual form." 29

These early instances of the new "archaeoscience" arise in no small part from investigations in which historians and archaeologists, working together, have started with traditional sources and questions, and incorporated new kinds of material evidence, whether cultural or biological in origin. The role of archaeologists, specialists in uncovering and understanding the material culture of past societies, is crucial, from the study of Palaeolithic life to that of nineteenth- and twentieth-century industry. ${ }^{30}$ At the other end of broad spectrum interdisciplinary history, life scientists are encountering strange patterns in the genetic transmission of devastating diseases or the geographic distribution of distinctive segments of the genetic codes of healthy people. They have begun to wonder -and sometimes write - about the historical situations that produced these patterns. Physicians and geneticists studying a childhood anemia with serious neurological consequences have found three unusual mutations on the north coast of Ireland. They detect their genomic tracks in a source population on the coast of northwest Norway. The last time those distant areas interacted sexually in a significant way was the ninth-century Viking invasion. The geneticists drew the historical inference that the $21^{\text {st }}$ century suffering of Irish children pinpoints the geographic origin of those ancient invaders as no text has ever done. ${ }^{31}$

\footnotetext{
${ }^{29}$ Lawrence Stone and Gabrielle M. Spiegel, "History and Post-Modernism," Past and Present (1992), 189-208, here 200.

${ }^{30}$ See on this last, e.g., Peter Stott, Looking for work: industrial archeology in Columbia County, New York: the emergence and growth of local industry as revealed in surviving sites and structures (Kinderhook, N.Y., 2007), and Douglas C. McVarish, American industrial archaeology: a field guide (Walnut Creek, Calif., 2008).

${ }^{31}$ Kate A. O'Donnell, Charles O'Neill, Orna Tighe, Giorgio Bertorelle, Eileen Naughten, Philip D. Mayne, and David T. Croke, "The mutation spectrum of hyperphenylalaninaemia in the Republic of Ireland: the
} 
A consilient approach would seek to confirm the pattern with independent evidence. In fact, unbeknownst to either party, a research group at the University of York is using genetics to rewrite the history of domestic mouse populations in the British Isles. Against earlier ideas that mice colonized Britain in the Neolithic, they have demonstrated from the phylogeny -a kind of genetic genealogy based on mutations-- of modern mice's mitochondrial DNA, the existence of a distinctive group appearing in Ireland, Scotland, the western edges of England, and in northwest Norway. It is entirely plausible from a historical and zoological perspective that new mice colonized these regions from Viking ships. ${ }^{32}$ The mouse and human disease genetics can be set alongside church fittings plundered from Ireland and refashioned into personal ornaments. The pattern of their placement in graves in northwestern Norway has now been linked with the early Viking attacks on Ireland. ${ }^{33}$ Each strand of evidence from the genetics of mice, humans, and archaeology and art history is completely independent. Yet the three sets of evidence fit together in perfect consilience, and pinpoint a region that specialized in the plundering of early medieval Ireland.

Recent studies not infrequently speculate on how modern Europeans' genetic disposition or resistance to various diseases links to the genetic bottleneck of the Black Death and the second global pandemic of plague $(1347-1722) .{ }^{34}$ Biostatisticians and

population history of the Irish revisited," European Journal of Human Genetics, 10 (2002), 530-538; cf. Johannes Zschocke, "Phenylketonuria mutations in Europe," Human Mutation, 21 (2003), 345-356.

${ }^{32}$ J. B. Searle, C. S. Jones, Gündüz, M. Scascitelli et al., "Of mice and (Viking?) men: phylogeography of British and Irish house mice," Proceedings of the Royal Society B: Biological Sciences, 276 (2009), 201207.

${ }^{33}$ Egon Wamers, "Insular finds in Viking Age Scandinavia and the state formation of Norway," in (eds.) H.B. Clarke, M. Ní Mhaonaigh, et al., Ireland and Scandinavia in the early Viking age (Dublin, 1998), 3772.

${ }^{34}$ Most frequently evoked is a hypothetical link between the CCR5-Delta32 allele which brings HIV-1 resistance, and the Black Death, see e.g., Michael McCormick, "Toward a molecular history of the Justinianic Pandemic," in (ed.) L.K. Little, Plague and the end of antiquity. The pandemic of 541-750 
geneticists have uncovered in the genomes of modern-day people striking traces of what look like the patterns of sexual conduct among fifth-century Anglo-Saxon invaders and Romano-Celtic conquered. ${ }^{35}$ Scandinavian surnames correlate significantly with genomic signals pointing to Vikings on the $\mathrm{Y}$ chromosome of $21^{\text {st }}$-century Britons. ${ }^{36}$ There is no reason similar methods cannot be applied to sixteenth-century Spanish settlers and native American populations. Such a genomic approach is revolutionizing our understanding of the people of the south Asia, throwing down new challenges to archaeologists of the Indus river valley and Sanskrit scholars of the Rig Veda that would have seemed inconceivable just a few years ago. ${ }^{37}$

History is the most gregarious of disciplines. We humans seem given to constantly wondering about new things as our own history unfolds in often unexpected ways. Even at our most narcissistic, we are inclined to wonder how we ourselves came to be in the situation where we find ourselves, whether we consider the economy, gendered

(Cambridge, 2007), 290-312, at 301. General evidence is accruing against the connection: P. Zawicki, and H. W. Witas, "HIV-1 protecting CCR5-Delta32 allele in medieval Poland," Infection, Genetics and Evolution, 8 (2008), 146-151, which seems to find reinforcement in the allele's reported frequency both in a medieval plague pit and a Bronze-Age population: B. Kremeyer, S. Hummel, and B. Herrmann, "Frequency analysis of the delta32ccr5 HIV resistance allele in a medieval plague mass grave," Anthropologische Anzeiger, 63 (2005), 13-22, and S. Hummel, D. Schmidt, B. Kremeyer, B. Herrmann, and M. Oppermann, "Detection of the CCR5-Delta32 HIV resistance gene in Bronze Age skeletons," Genes and Immunity, 6 (June, 2005), 371-374. The debate nevertheless remains open; see the exchange of S. K. Cohn, Jr., and L. T. Weaver, "The Black Death and AIDS: CCR5-Delta32 in genetics and history," QJM: an International Journal of Medicine, 99 (2006), 497-503, and B. H. Bossak, "AIDS and the Black Death," QJM: an International Journal of Medicine, 100 (2007), 144-145.

${ }^{35}$ Mark Thomas, Michael P.H. Stumpf, and Heinrich Härke, "Evidence for an apartheid-like social structure in early Anglo-Saxon England," Proceedings of the Royal Society of London, series B, Biological sciences, 273 (2006), 2651-2657. Dr. Thomas presented his latest findings for lively discussion by archaeologists, historians and biologists at the "Medieval Archaeology in the $21{ }^{\text {st }}$ Century" lectures series at Harvard University two years ago.

${ }^{36}$ Georgina R. Bowden, Patricia Balaresque, Turi E. King, Ziff Hansen, Andrew C. Lee, Giles PerglWilson, Emma Hurley, Stephen J. Roberts, Patrick Waite, Judith Jesch, Abigail L. Jones, Mark G. Thomas, Stephen E. Harding, and Mark A. Jobling, "Excavating past population structures by surname-based sampling: the genetic legacy of the Vikings in northwest England," Molecular Biology and Evolution, 25 (2008), 301-309.

${ }^{37}$ D. Reich, K. Thangaraj, N. Patterson, A. L. Price, and L. Singh, "Reconstructing Indian population history," Nature, 461 (2009), 489-494. 
patterns of labor, or the environment. And not a few of us wonder how the humans who preceded our short spans came to make the world they lived in and that we have inherited. In the face of our suddenly deferred mortality, we are beginning to grasp that human health is itself a historical phenomenon, and to seek to measure the present against the past. Pension and other records of the Union Army allow economists to demonstrate the sharp decline in the health of American males after 1830. One way of interpreting this extraordinary data is that the average later nineteenth-century American male experienced the life cycle at a substantially accelerated rate compared to our current norm. ${ }^{38}$ Biologically, a 35- or 40-year old in 1870 might have looked and felt more like a 55-year old in 2000. And health has economic implications in the past as in the present. From the bones of the individuals who built those ancient worlds, serious scholars are attempting to construct an economic history of Europe from the Roman empire to Shakespeare, or of pre-Columbian America. ${ }^{39}$

Archaeology and especially the natural sciences are producing huge amounts of new data that constitute new historical evidence, albeit of types and qualities that are still mostly unfamiliar. Indeed, the new historical data is starting to arrive in such enormous quantities that it imposes quantitative and statistical approaches that are common in only a few sub-provinces of twenty-first-century historical investigation. The new evidence from material culture and things, from the microscopic or even molecular scale to that of buildings, blankets and ships, dispels the idea that material culture concerns only students

\footnotetext{
${ }^{38}$ Dora L. Costa, and Richard H. Steckel, "Long-term trends in health, welfare, and economic growth in the United States," Historical paper 76, National Bureau of Economic Research (Cambridge, MA, 1995).

${ }^{39}$ Nikola Koepke, and Jörg Baten, "The biological standard of living in Europe during the last two millennia," European Review of Economic History, 9 (2005), 61-95; Richard H. Steckel, and Jerome C. Rose, "Patterns of health in the western hemisphere," in (eds.) R.H. Steckel and J.C. Rose, The backbone of history: health and nutrition in the Western Hemisphere (Cambridge, 2002), 563-579.
} 
of a less proximate past whose very deepness has helped filter out the written record. Historians of Ottoman Turkey, seventeenth-century Maryland or early twentieth-century America understandably may feel at first that their subjects are rich enough in written records that they can afford to neglect material evidence. But recent work shows that would be unwarranted. ${ }^{40}$

One of the extraordinary aspects of the new knowledge emerging from the scientific analysis of our material past is that it escapes the filters -conscious or unconscious-- imposed by the cultures of power that have generated and preserved the written record until today. ${ }^{41}$ The potential of natural scientific approaches to illuminate the lives and experiences of the voiceless is huge. Thanks to the Union Army's written records, we know infinitely more about the lives and historical experience of health of hundreds of thousands of nineteenth-century men than we do about the women with whom they lived. But even if, compared to men, these women have left small and uneven tracks across the written records, the survival rate of their bones is roughly the same as that of men, and they tell a precise and detailed tale of women's sufferings, their work patterns, diet, even their migratory movements. Bioarchaeological analyses, for instance, illuminate the life experiences of pioneer women buried in nineteenth-century cemeteries across the Great Plains.

The burial ground at the Cross Homestead tells a remarkable story about a family which settled in Sangamon County, Illinois, just two years before young Abraham

\footnotetext{
${ }^{40}$ See for instance the role of material culture in Laurel Ulrich, The age of homespun: objects and stories in the creation of an American myth (New York, 2001).

${ }^{41}$ Thus side-stepping in some ways the kinds of difficulties discussed by, e.g., Dipesh Chakrabarty, Provincializing Europe: postcolonial thought and historical difference (Princeton, N.J., 2000).
} 
Lincoln landed there. ${ }^{42}$ It illuminates the biomolecular world in which the young Lincoln rose to prominence. Valuable information comes from the county records and more general work on the health of the American population in those decades. Consilience of the material with the written record is clear, for instance in the archaeological evidence for the expected heavy rates of juvenile mortality $(62 \%)$ or in the possible signs of malaria. ${ }^{43}$ But in this family at least, women died on average age at 25 years, a "staggering" seventeen years younger than men, at 42 years. Stable isotopes suggest that the pioneers' diet relied much on the plant type likely represented by corn, and on freshwater fish. Several family members showed clear signs of iron-deficiency anemia, which potentially stemmed from the presence of malaria in that part of Illinois. The majority of the Cross family experienced severe stress such as infectious disease or malnutrition in their first twelve or so years of life, to judge from the traces the stress has left in their tooth enamel. Those same teeth show that the family suffered from high rates of cavities and tooth loss, presumably due at least in part to periodontal disease and the probable prominence of cavity-causing corn in their diet. Females suffered almost four times the dental decay of males, which has suggested that they perhaps consumed proportionately more, and more frequently, of whatever was causing the decay. Their bones show that the women shouldered a workload no less heavy than that of the men. The men's legs testify to heavy labor, perhaps behind a plow, and their teeth are worn in an unusual pattern that could indicate that they habitually held plow reins in their teeth.

\footnotetext{
${ }^{42}$ See David Herbert Donald, Lincoln (New York, 1995), 38-64, on this formative period and place in Lincoln's life.

${ }^{43}$ This portrait relies on Clark Spencer Larsen, Skeletons in our closet: revealing our past through bioarchaeology (Princeton, N.J., 2000), 203-227; cf. the picture, telling both by its similarity and differences, that Larsen paints of a group of seventeenth-century Maryland colonists from Patuxent Point, ibid., 185-202, down to the evidence for the habitual clamping of a clay pipe in someone's teeth.
} 
The number of individuals available for study was small, and it remains to be seen how far their extremely challenging life experience can be extrapolated to the majority of nineteenth-century pioneers. But the day is coming when we will know just how exceptional the stories are of the rare women whose gnarled fingers put pen to paper. Though the voices have forever been stilled, their children too, and their slaves, on whose backs so much of America was built, still have stories to tell that are etched in the molecules of their earthly remains. ${ }^{44}$

Whether or not professional historians become involved, scientists increasingly reflect on the implications for history of their findings and experiments, and vice versa. This is leading scientists to need historians as much as we need scientists. I remember overhearing at a conference a conversation between two accomplished scientists about an apparent anomaly in recent scientific data concerning global industrial pollution in the northern hemisphere that had been linked to the fall of the Roman empire. Was the data wrong? After all it was common knowledge that the Roman empire fell in 476, but the preliminary data did not show a sharp drop-off then. ${ }^{45}$ The scientists were surprised --and relieved-- to learn that archaeologists and historians now view the breakdown of the ancient economy as a longer and more complex phenomenon that stretched out into the sixth or seventh century. The scientific data under discussion were likely not wrongly dated after all. As the data and discoveries pile up, it would be a shame if scientists were

\footnotetext{
${ }^{44}$ For a stimulating effort to construct a kind of biography from the remains of a seventh-century AngloSaxon woman, see Robin Fleming, "Writing biography at the edge of history," The American Historical Review, 114 (2009), 606-614.

45 See, e.g., Sungmin Hong, Jean-Pierre Candelone, Clair C. Patterson, and Claude F. Boutron, "Greenland ice evidence of hemispheric lead pollution two millennia ago by Greek and Roman civilizations," Science, 265 (1994), 1841-1843; W. Shotyk, D. Weiss, P.G. Appleby, A.K. Cheburkin, R. Frei, M. Gloor, and et. al., "History of atmospheric lead deposition since 12,370 14C yr BP from a peat bog, Jura Mountains, Switzerland," Science, 281 (1998), 1635-1640, and Jerome O. Nriagu, “Tales Told in Lead,” Science, 281 (1998), 1622-1623.
} 
deprived of interaction and insight from us, the professionals of the human past, about possible implications of their data. Many errors and misleading hypotheses can be avoided, and better questions and answers obtained. Besides, the interpreting is going to be done whether we take up the challenge or not. It will be better for all concerned if we are involved.

Such new historical insights exhilarate. Nevertheless, the evidence for the human past which is emerging from science and archaeology poses great challenges for historians. Engagement with the natural sciences will not come cheaply, in any sense of the word. The monetary challenge of archaeoscience can be imposing, and the grant application procedures for scientific funding are considerably more complex and arduous than what we are accustomed to. But, for starters, there is no reason that we historians cannot be part of grant applications in which our more experienced scientific colleagues take the lead. If the science and the history are sound, there is no reason not to expect success at the normal rates in these matters.

Beyond cost, the abundance of the data poses a dual challenge, for it is incremental in two ways. It increases, voluminously, the amount of evidence that historians must consider to reach a less incomplete understanding of the human past: broad spectrum interdisciplinary history introduces a new and much more capacious evidentiary basis for our work. The new data augment but in no way replace the evidence on which historians have worked for the last 400 years. In other words, the new evidence multiplies the volume of our work, already considerable.

Moreover, a consilient approach requires additional competences to deal intelligently with the additional data. Historians must gain familiarity with at least the 
basics of methods which for most of us are quite unusual. The new data result from highly technical, often expensive types of analyses, performed by specialists in specialized labs, with complex methods of authentication and statistical sifting. One cannot simply look at a DNA microchip array and prove a historical point. Our universities and primary and secondary schools are still not delivering a level of scientific literacy that is commensurate with competing societies around the globe. Yet scientific literacy is indispensable for grasping the power and limitations of the new historical data and methods.

A further challenge is more subtle. It arises from the perceived or real authority claims of the new evidence, which lead directly to the question of the new data's relation with the old data. The new data emerge from the ultra-prestigious laboratories of the leading institutions of modern investigation and survive the severe peer review process that characterizes the upper echelon of modern science. But that does not mean that the new evidence automatically trumps the sources historians have painstakingly discovered and analyzed in preceding generations. Nor is the inverse true.

The challenge here is that the new data complement and are corrective to the old data. Epistemologically independent of our traditional written sources, the new evidence for a consilient approach to the human past remains necessarily subject to critical scrutiny. Just as when we use research in material culture or in archaeology, historians who turn to the new evidence from the natural sciences will have to discriminate carefully between the results of laboratory or statistical analyses, and the interpretation of those results offered by the scientists or archaeologists. Even more difficult, but more liberating also: modern historians sometimes will have to learn to free our established 
historical sources from the unconscious gloss, the received interpretations in which our understanding of the sources has become enmeshed. Only when we are able to strip from the "well-known" historical evidence the veil of familiarity will we come to view the old testimony of well-known sources with freshly critical eyes, and discover where the consilience lies. Insofar as the testimony of the written word and the material evidence stem from the past reality of the human experience, there will be places where they coincide. But those two types of evidence are different vantage points on a complex and multi-faceted reality which even at the moment of occurrence was often only dimly visible. Processes of transformation and deformation mediate the different windows of knowing through which we peer. Whether mental or physical, those windows have real impact. And so it would be naïve to expect that consilient analyses will result in unfailing and immediate convergence. Contradiction too can be expected. If we welcome it and scrutinize its sources with wisdom, the resulting insights may cause us to understand in new ways the written evidence we have known so long. The ultimate challenge of the consilient approach will be to achieve a synthesis that affords the appropriate place and weight to new evidence and rethought old evidence.

Notwithstanding the common undergraduate assumption that people who lived in the past were stupider than people who are smart enough to live right now, past humans and past reality were no less complicated than those of the present. The complexity of the past requires a complex research strategy. Hence another set of challenges arises from the necessary specialization of multiple research approaches coordinated into carefully 
organized team work. ${ }^{46}$ In itself this should not be a problem. Historians need look no further than a well-run archaeological excavation to see how humanistic disciplines are able to assemble teams of highly skilled specialists in the natural sciences, various subdisciplines of archaeology, art history, and, increasingly, historians, to work together from the very formulation of the research questions to final publication.

But what does this imply about our venerated single-authored monograph? Since 1850, research has increasingly specialized by period and by theme. Americanists now specialize in a particular set of questions and approaches for a particular decade or two in the life of their historical subject, Europeanist historians specialize in a century or so, and medievalists and Roman imperial historians specialize in early, middle, and late, with appropriate subdisciplinary focuses in environmental, economic, gender, or diplomatic or cultural history, and so on. Our ever sharpening focus has brought remarkable advances in the understanding of the past. But the narrowing of view it necessarily entails has already imposed multi-authorship in some areas. Historians have no difficulty distinguishing between a single author's broad-gauged work of stimulating synthesis and authoritative in-depth surveys, such as the Cambridge histories, by multiple authors who sign their individual chapters. Is it so large a step to multi-authored monographs or research articles? What, some may object, about promotion committees faced with the multiple authorship that the new archaeoscience and its consilient approach to historical problems often imposes? That is surely a red herring. Nobel Prize committees seem to have little difficulty determining who among multiple authors deserves the bulk of the credit for discoveries in the natural and the applied sciences. Scientists, all of whose

\footnotetext{
${ }^{46}$ See the reflections of Philip D. Curtin, "Overspecialization and remedies," in (eds.) R.H. Steckel and J.C. Rose, The backbone of history: health and nutrition in the Western Hemisphere (Cambridge, 2002), 603608 .
} 
publications feature multiple authorship, rise to tenure every day in North American universities. Why should it be any different for the historians who dare to take the new interdisciplinary path toward the broad spectrum human past?

Certainly the challenges of the new archaeoscience are many and great. But so is its promise. A quarter century ago, the president of the American Historical Association mused deeply about the complexities of human history, and the importance of matching the "manifest" history of elections, wars, and laws with the "latent" history at work in the same time and place, that is, the changes in demography, in disease pools, in the environmental framework in which human events played out, and other ongoing processes of which contemporaries were unaware yet could not escape. ${ }^{47}$ Informed contemporaries were well aware of the events of manifest history, and in them they tended to locate the power of explanation. Historians of all descriptions, particularly social historians, have made great strides at uncovering parts of the latent histories of their various subjects. The most alluring promise of the consilience of historical and natural scientific exploration and explanation is that it will unveil for us hitherto latent aspects of human history in whose discovery we are already avowedly interested: diet, demographic trends, weaning patterns, migration, health and disease, communications networks, labor patterns and technologies, climate change, environmental degradation and regeneration.

But perhaps the most exciting promise lies in the insights that we cannot anticipate. Those insights throw out new historical questions. Who, just ten years ago, would have thought it even possible to debate the mating patterns of the Anglo-Saxon

\footnotetext{
${ }^{47}$ Bernard Bailyn, "The challenge of modern historiography," American Historical Review, 87 (1982), 124, at 11 .
} 
men who conquered Britain? As we have seen, the genetic evidence of modern Britons has opened this question up for renewed examination in light of the archaeological, written and linguistic evidence, and made it an imperative one if we are to understand the trend of early British civilization, even as it underscores the importance of a gendered approach to early medieval Britain. ${ }^{48}$ Who would have thought that volcanic eruptions half a world away would impinge on the reorganization of early medieval Europe? Or that the barrels of herring consumed by working-class Italians in Leonardo da Vinci's Rome could be detected five centuries later and demonstrate the everyday impact of new oceanic trading systems and food industries?

Yes, there are challenges. But they are challenges that other disciplines have surmounted before us. And the promise is peerless. The new archaeoscience will bring light to places and questions incompletely illuminated by the written record. It will add a powerful new perspective on those more fully recorded in our conventional sources. But perhaps most movingly, the consilience of the natural science and historical investigation promises to restore voice to the voiceless. The pioneer women of the Plains, the slave uprooted from her ancestral home to perform on a foreign shore unceasing labor which still can be read in her worn bones, a child whose multiple illnesses in nineteenth-century London fill in the biological background to Industrial Revolution: these are human actors, deprived of testimony in their own lifetime, and given voice by the new methods of archaeoscience. The promise is clear: a unified human history that rises above the false dichotomy of written and non-written evidence, that does not begin in the recent past of the third millennium B.C., but in the beginning, with the emergence of our ancestors in Africa, and follows their adventure down to the present day. A new broad spectrum

\footnotetext{
${ }^{48}$ See above, note 35.
} 
approach to the human past uses critically, rigorously, and sympathetically the entire range of evidence -material and written - whose consilience will bolster our confidence in the inferences we draw to illuminate the lives of the women and men who have preceded us. That is a promise worthy of the challenge of the new interdisciplinary approach to human history in the $21^{\text {st }}$ century. 